\title{
AN EASY TECHNIQUE FOR Rh GROUPING \\ BY
}

\author{
I. D. P. WOOTTON
}

From the Royal Army Medical College, London, S.W.I

(RECEIVED FOR PUBLICATION DECEMBER 2, 1949)

The method of grouping described here is now in routine use in the serology laboratory, Royal Army Medical College. It requires only $0.0065 \mathrm{ml}$. $(1 / 150 \mathrm{ml}$.) of serum for each test and the technique of setting up and reading is quick and easy. In addition the labour of washing up afterwards is almost eliminated.

Equal volumes of grouping serum and saline red cell suspension are mixed on a "perspex" surface which is then inverted and incubated in a moist atmosphere. The drop does not wet "perspex" and therefore hangs from the underside as a hemisphere. The red cells sediment in the drop and collect in the tip just as they do in a tube. After incubation a coverslip is applied and the preparation is examined microscopically for agglutination.

\section{Apparatus}

"Perspex" Slides.-These are made from odd lengths of " perspex"; a convenient size is $10 \mathrm{~cm} . \times 2.5 \mathrm{~cm} . \times 0.5 \mathrm{~cm}$. The front surface of each slide is divided into four equal areas by means of three transverse cuts made with a triangular file and extending part way through the thickness of the slide. Each area, about $2.5 \mathrm{~cm} . \times 2.5 \mathrm{~cm}$., is sufficient for one test, and the areas are conveniently numbered by engraving the back surfaces of the slides with a sharp instrument.

Moist Chamber.-This may be improvised from a petri dish. We use a box made from a "perspex" museum jar and provided with a close-fitting lid. Two strips are cemented along the inside long walls. The slides fit transversely across the box so that their extreme ends rest on the strips. A pad of moist blotting-paper is placed on the bottom.

\section{Setting-up}

Volumes are measured by calibrated capillary pipettes or finely drawn waxed droppers. In either case equal amounts $(1 / 150 \mathrm{ml}$. or less) of grouping serum and $2 \%$ red cell suspension are taken up and deposited gently together in the middle of one of the areas. The mixed drop is stirred carefully with a glass needle without spreading the drop over the surface. When all tests have been set up, the slides are inverted and placed in the moist chamber so that the drops hang suspended from the under surface. The chamber is incubated at $37^{\circ}$ for two hours.

\section{Reading}

Naked eye readings of the sedimented red cells are possible, but we always confirm such readings microscopically. The slides are removed from the chamber and held in the inverted position. Each drop is then lowered so that it contacts the centre of a $\frac{3}{4}$-in.-round coverslip, which is drawn up by capillary attraction into contact with the 
slide. The slide is then turned right side up and examined under the low power of the microscope. The fluid is sufficient to fill the space between coverslip and slide. Most of the red cells remain in the centre and the cell density becomes less towards the edges. Any agglutination is easily seen. After use, the coverslips are removed. The slides are rinsed under the tap, dried with a cloth, and are immediately ready for use again.

\section{Sensitivity}

Serial dilutions of anti-D sera have been incubated against $\mathbf{R h}$-positive cells, using this method parallel with the standard tube technique (Mollison, Mourant, and Race, 1948). Little difference in sensitivity has been found (see Table). With

TABLE

Comparison of Present Method and Standard Tube Technique

(Mollison, Mourant, and Race, 1948)

\begin{tabular}{|c|c|c|c|c|c|c|c|}
\hline & \multirow{2}{*}{\multicolumn{3}{|c|}{$\begin{array}{l}\text { Dilution of } \\
\text { Test Serum }\end{array}$}} & \multicolumn{2}{|c|}{ Present Method } & \multicolumn{2}{|c|}{ Tube Method } \\
\hline & & & & $\underset{\text { A }}{\text { Cell Sample }}$ & $\underset{\text { B }}{\text { Cell Sample }}$ & $\underset{\text { A }}{\text { Cell Sample }}$ & $\underset{\text { B }}{\text { Cell Sample }}$ \\
\hline $1: 1$. & .. & .. & .. & +++ & +++ & +++ & +++ \\
\hline $1: 2$ & $\cdots$ & . &. & ++ & +++ & +++ & +++ \\
\hline $1: 4$ & $\cdots$ & $\cdots$ &. & +++ & +++ & +++ & ++ \\
\hline $1: 8$ & $\cdots$ & $\cdots$ & $\because$ & ++ & ++ & ++ & +++ \\
\hline $1: 16$ & .. & .. & .. & + & ++ & + & ++ \\
\hline $1: 32$ & . & $\cdots$ &. & $(+)$ & ++ & + & ++ \\
\hline $1: 64$ & .. & . &.. & - & $\mathbf{w}$ & $\mathbf{w}$ & - \\
\hline $1: 128$ & $\cdots$ &. &. & - & - & - & - \\
\hline
\end{tabular}

the present technique, cells are not drawn into and ejected from a pipette. Thus in a strong reaction almost all the cells are found stuck together in a continuous sheet.

The method is also suitable for ABO grouping, $\mathrm{Rh}$ genotyping, and titration of saline agglutinins.

I have to thank Mr. F. C. Pinion for his invaluable help in developing this technique and making the first set of apparatus. I am indebted to the Director-General, Army Medical Services, for permission to publish.

\section{REFERENCE}

Mollison, P. L., Mourant, A. E., and Race, R. L. (1948). Medical Research Council Memorandum No. 19. London: H.M. Stationery Office. 